\title{
RISK-BASED CONCEPTUAL SHIP DESIGN OF A BULK CARRIER ACCOUNTING FOR ENERGY EFFICIENCY DESIGN INDEX (EEDI)
}

(DOI No: 10.3940/rina.ijme.2021.a1.638)

Y Garbatov, Centre for Marine Technology and Engineering (CENTEC), Instituto Superior Técnico, University of Lisbon, Portugal, and P Georgiev, Technical University of Varna, Varna, Bulgaria

KEY DATES: Submitted: 27/03/2020, Final acceptance: 04/11/2020; Published: 25/03/2021

\section{SUMMARY}

The paper covered a study aimed at developing a risk-based conceptual ship design method for bulk carriers, while taking into account the life cycle assessment and energy efficiency of the ship propulsion system. The study included conceptual ship design as a part of the risk-based ship design approach. In such conceptual design, using the long-time experience and statistics, the main dimensions and hull form, resistance and propulsion, weights, initial stability, freeboard, seakeeping and manoeuvrability were initially derived and the capital expenditure, operational expenditure, and decommissioning expenditure obtained. An optimal design solution was obtained, based on the energy efficiency design index, shipbuilding, operation, and resale costs at the end of the service life, which were used as input variables in a riskbased analysis.

\section{NOMENCLATURE}

B Breadth $(\mathrm{m})$

$\mathrm{C}_{\text {air pen }} \quad$ Penalty for air pollution

CAPEX Capital expenditure

$\mathrm{C}_{\text {ATS }} \quad$ Cost of one-tonne accidentally spilt oil to be cleaned $(€)$

$\mathrm{C}_{\mathrm{b}} \quad$ Block coefficient (-)

$\mathrm{C}_{\text {cargo }} \quad$ Cost associated with the loss of cargo (€)

$\mathrm{C}_{\text {cargo/tonne }}$ Cost of a tonne of cargo ( $€$ )

$\mathrm{C}_{\text {EEDIpen }}$ Penalty for air pollution of one $\mathrm{gCO}_{2} /$ tonnemile above required EEDI $(€)$

$\mathrm{C}_{\text {human }} \quad$ Cost associated with the loss of human life $(€)$

$\mathrm{C}_{\text {resale }} \quad$ Resale cost of the ship $(€)$

$\mathrm{C}_{\text {ship }} \quad$ Ship cost $(€)$

$\mathrm{C}_{\text {spill, air }}$ Cost of the accidental spill and penalties due to air pollution $(€)$

D Depth (m)

$\mathrm{d}^{\mathrm{cd}} \quad$ Depth of the corrosion degradation (mm)

DECEX Decommissioning expenditure

DW Deadweight (tonne)

EEDI Energy Efficiency Design Index

$\mathrm{f}_{\text {cargo }} \quad$ Percentage of cargo lost (-)

$\mathrm{f}_{\text {crew }} \quad$ Probability of loss of human life (-)

$\mathrm{F}_{\mathrm{n}} \quad$ Froude number (-)

$f_{\text {shore }} \quad$ Probability of the amount of spill to reach the shoreline

$\mathrm{f}_{\text {spill }} \quad$ Percentage of oil spill (-)

$\mathrm{g}_{\mathrm{i}}(\mathbf{X}) \quad$ Limit states function $\mathrm{i}$

ICAF Implied Cost of Avoiding a Fatality

IMO International Maritime Organization

L Length between perpendiculars (m)

$\mathrm{M}_{\mathrm{i}} \quad$ Safety margin for $\mathrm{i}^{\text {th }}$ limit states

$\mathrm{M}_{\mathrm{SW}} \quad$ Still water bending moment (kN.m)

$\mathrm{M}_{\mathrm{W}} \quad$ Vertical wave-induced bending moment (kN.m)

$\mathrm{n}_{\text {crew }} \quad$ Number of crew members (-)

OPEX Operational expenditure

$\mathrm{P}_{\text {cargo }} \quad$ Amount of cargo carried (tonne)
$\mathrm{P}_{\text {fuel carried }}$ Amount of fuel carried (tonne)

$\mathrm{P}_{\mathrm{w} \text {, ae }} \quad$ Power of the auxiliary engines $(\mathrm{kW})$

$\mathrm{P}_{\mathrm{w}, \mathrm{me}} \quad$ Power of the main engine $(\mathrm{kW})$

Risk $_{\text {failure }}$ Risk associated with the ship failure and its consequence costs $(€)$

Risk $_{\text {measure }}$ The cost of the implemented ship safety measures in redesigning the ship $(€)$

Risk $_{\text {total }} \quad$ Total expected risk $(€)$

SFOC Specific fuel oil consumption

$\mathrm{T} \quad$ Draught $(\mathrm{m})$

$\mathrm{V}_{\mathrm{s}} \quad$ Ship speed (kn)

$\mathrm{Z} \quad$ Midship section modulus $\left(\mathrm{cm}^{3}\right)$

$\beta_{\mathrm{i}} \quad$ Beta reliability index related to the $\mathrm{i}^{\text {th }}$ limit state

$\gamma \quad$ Discount rate

$\rho$ Correlation coefficient between the two

linearized safety margins

$\sigma_{\mathrm{p}} \quad$ Allowable permissible stress $\left(\mathrm{N} / \mathrm{mm}^{2}\right)$

$\tau_{\mathrm{C}} \quad$ Coating life (years)

$\tau_{\text {ship, o }} \quad$ Time of permanent cost (years)

$\tau_{\text {ship } \mathrm{t}} \quad$ Transition time (years)

$\tau_{\mathrm{t}} \quad$ Transition life (years)

$\Phi_{\mathrm{m}} \quad$ m-dimensional normal distribution function

\section{INTRODUCTION}

Shipping accounts for transporting about $90 \%$ of the global trade, and it is considered to be the least environmentally damaging mode of transportation (UNCTAD, 2020). The International Maritime Organization (IMO) has been continually issuing resolutions and recommendations related to pollution prevention issues such as oil pollution, chemical pollution, sewage, garbage, air pollution, and Green House Gas (GHG) emissions, ballast water management, biofouling, anti-fouling systems, ship recycling and port reception facilities. The chronology of MARPOL Annex VI amendments and recent studies concerning the emission evaluation from ships are discussed in (Blasco et al., 2014). 
A study performed by Smith et al., (2016) analysed the $\mathrm{CO}_{2}$ emissions from international shipping and possible reduction targets and their associated pathways studying different scenarios by a broad range of possible features, related to the regulations, demand, and techno-economic characteristics. The analysed scenarios appear to be a solid basis for further studies.

Potential power-setups, fuels, and hull designs capable of satisfying future Energy Efficiency Design Index (EEDI) requirements were analysed by (Lindstad and Bøa, 2018) concluding that a slender hull in combination with a conventional engine is the most cost-competitive solution capable of satisfying the 2020 EEDI requirements, while hybrid power setups combined with slender designs are the most cost-competitive solution for the 2025 EEDI requirement.

IMO recognises the importance of adopting the risk assessment procedures in their decision process by defining the Formal Safety Assessment (FSA) (IMO, 2002, 2005a, 2008, 2013) as a systematic method aimed at enhancing maritime safety, including the protection of life, health, maritime environment, cargo and ship integrity by using risk and cost-benefit assessments.

The FSA method (IMO, 2013), as presented in Figure 1, is inspired by IMO, and is based on a Quantified Risk Analysis (QRA) that provides a broad application of QRA to marine transportation. It is a method aimed at enhancing maritime safety, including the protection of life, health, the maritime environment, and property.

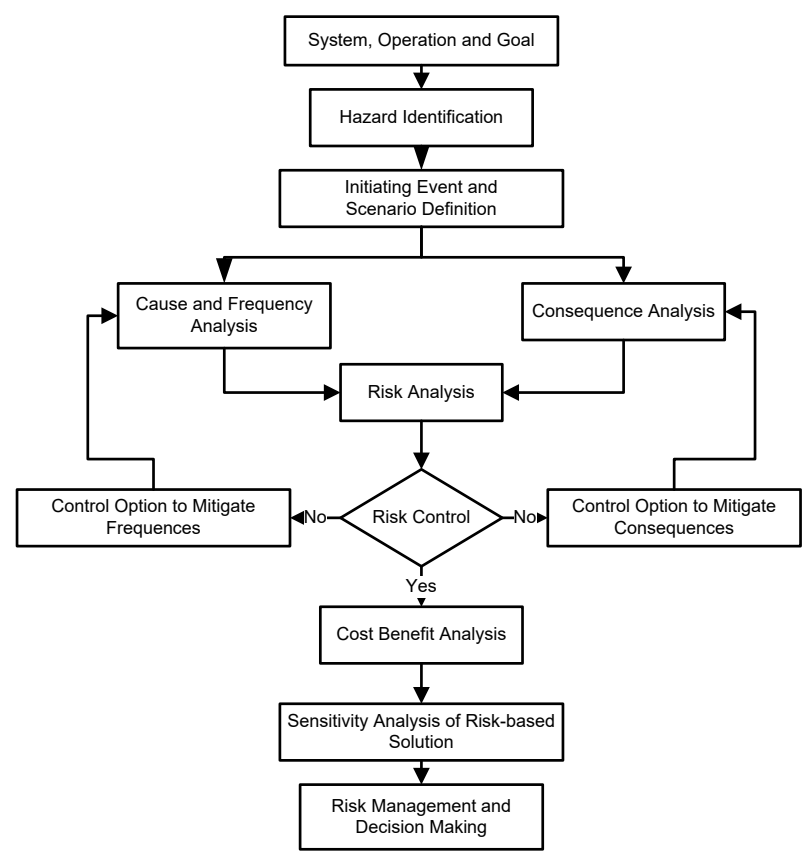

Figure 1 Formal Safety Assessment

Concerns are being raised because many of the already built ships cannot adequately meet new requirements. For example, the recent developments introduced by IMO have an impact on the performance of the risk-based design (Papanikolaou et al., 2009) and short sea shipping (Papadimitriou et al., 2018).

A preliminary design of the Suezmax tanker, accounting for oil outflow risk from ship-ship collisions, is presented in (Tan et al., 2019). The input variables include the main dimensions and block coefficient, longitudinal centre of buoyancy, and height of double bottom and width of double skin sides. The utility level, which is the weighted sum of steel weight, resistance, mean outflow, and cargo capacity or each of the design variants were compared for different weighing factors. The amount of oil spill represented the environmental consequences of tanker collisions.

Recently, there has been an increase in research related to holistic ship design (Papanikolaou et al., 2009, Boulougouris et al., 2011, Plessas et al., 2018). A review of recently published holistic design models is presented by Nowacki, (2019) concluding that in each phase of the ship life cycle, three objectives, i.e. economic efficiency, safety, and environmental impact of the ship as an engineering product need to be considered.

The growing sea transportation in the Arctic and Antarctic increased the risks of accidents, and Bergström et al., (2016) presented a framework for holistic goal- and riskbased design of arctic maritime transport systems treated as a hierarchy of subsystems.

A design framework based on the risk that covers structural failure together with hazards such as accidental spills, loss of cargo, ship, and crew members was proposed in (Garbatov et al., 2018b). The framework was extended into a risk-centred maintenance method to determine the maintenance plan of the ship hull structural system (Garbatov et al., 2018a), which can be used in the early design stage.

The need for compliance with the EEDI requirements put many challenges to designers and ship-owners. Energy efficiency is included as a merit function for multiobjective design optimisation for the conceptual design of Aframax oil tankers and container ships (Boulougouris et al., 2011). A parametric multi-objective optimisation procedure for Ro-Pax vessels and container ships accounting for a reasonable rationally supported balance between economy, efficiency, and safety of the ship and the environment was performed in (Plessas et al., 2018).

The modern principles of risk-based design and the environmental requirements on maritime transport are the main motivation of the present study. The objective is to develop a risk-based conceptual ship design accounting for the life cycle assessment and energy efficiency of the ship propulsion complex. Along the lines of the conceptual ship design, the optimal design solution is defined based on the energy efficiency design index, (EEDI), shipbuilding, operation, and resale cost at the end 
of the service life, which are then used as input variables in the risk assessment. The developed risk-based design approach has been used for the conceptual design of a bulk carrier in the study presented here.

\section{CONCEPTUAL SHIP DESIGN}

The formulation of the conceptual ship design assesses the owner's specification requirements. These are related to ship type, cargo capacity, length, breadth, speed, life cycle cost, including capital expenditure (CAPEX), operational expenditure (OPEX) and decommissioning expenditure (DECEX) and probability of satisfying different operational criteria and structural analysis. Specification requirements consider aspects that may relate to the ship hull descriptors, shaft horsepower, lightweight, dead weight, cargo capacity, free-board, initial stability, seakeeping, manoeuvrability, midship section requirements, including still water and wave-induced loads as well as the probability of structural failure. Due to the large number of parameters and criteria that are considered, the Pareto optimisation algorithm is employed to establish the optimal design solution in defining the main characteristics of the ship.

The conceptual design is defined as a compromise decision support problem with multiple goal constraints. Given the owner's requirements about cargo deadweight, speed, range, regulations, and existing data on similar ships to find the main ship dimensions and ship hull form descriptors like the length between perpendicular (L), breadth (B), depth (D), draught (T), block coefficient $\left(\mathrm{C}_{\mathrm{b}}\right)$ and ship speed $\left(\mathrm{V}_{\mathrm{s}}\right)$.

During the design process, a series of relationships need to be employed that relate to steel weight, outfit weight, Froude number $\left(F_{n}\right)$, displacement, propulsion power, machinery weight, deadweight, daily fuel consumption, energy efficiency, sea days, fuel carried, crew, stores, and water, cargo deadweight, port stay days, round trips per year, redesign measure cost, ship cost, capital cost, operational cost, voyage cost, annual cost and decommissioning cost.

The design solution satisfies the system constraints related to the free-board, initial stability, seakeeping conditions, manoeuvrability, and the dimensional ratios $\mathrm{L} / \mathrm{B}, \mathrm{L} / \mathrm{D}$, $\mathrm{L} / \mathrm{T}, \mathrm{F}_{\mathrm{n}}$, deadweight (DW) are within the limits that reflect the designer's experience-based insight (Lyon and Mistree, 1985).

The conceptual design is defined by multiple objectives and constraints, and computational methods in finding a suitable solution. The optimisation techniques used may be categorised into mathematical programming techniques involving genetic algorithms and stochastic process techniques, where the Markov process is employed as well as statistical methods like the design of experiments (Rao, 2009). The choice of which optimisation technique to be used depends on the type of the optimisation problem, the number of design variables and their interaction, numerical tools employed in the analysis, etc.

The optimisation procedure may generate a feasible region of possible design points. Not all encountered design solutions are optimal for any given set of objective functions, and a trade-off between the objective functions needs to be analysed (Keane et al., 1991). In this regard, the Pareto Frontier optimality solution may be employed (Komuro, Rié et al., 2006), which defines all optimal solutions represented in the design space. The Pareto optimal solution can be defined as a solution where any improvement in one objective results in the worsening of at least one other goal (Messac and Mullur, 2007). Employing the Pareto Frontier, and accounting for the existing constraints and a utility function to rank the different designs solutions, or by using $2 \mathrm{D}$ or $3 \mathrm{D}$ scatter diagrams, the most attractive design solution may be identified. Additional constraints can also be introduced to represent the reliability to choose the most appropriate design solution.

The resistance and propulsion estimates, in the conceptual design phase, widely employs regression equations or the mathematical model as given in (Holtrop and Mennen, 1982) providing the hull resistance and engine power demand, used to select a propeller engine set (Carlton, 1994). A possible alternative solution is the use of other methods as presented in (Patullo and Thomson, 1965, ITTC, 1978) methods.

The lightship weight is split into subsystems like hull structure, equipment and outfitting, and machinery. The hull structure weight includes the main hull structure, superstructure, and deckhouses. The equipment and outfitting category includes pipes, deck outfitting, anchors, rudder, non-propulsion mechanical equipment such as deck machinery, steering engine, generators, ventilation systems, refrigeration systems, hull piping systems and pumps, and electrical systems. The total machinery weight includes the main engine, auxiliary machinery, propeller, propeller shaft, engine spares, controls, and liquids in machinery.

To estimate the structural weight, regression equations based on a statistical analysis of existing ships can be used (Benford, 1967, Cudina et al., 2010). To calibrate the regression equations that will be employed to estimate the weight of different subsystems, information taken from four recently built similar ships are used (Lee et al., 2007).

For the deadweight estimation of the ship, with sufficient comparative data from similar ships on the vessel's displacement, the approach that is applied only for deadweight carriers as presented in (Kupras, 1976 and Lamb, 2003) can be employed.

The free-board is defined using a parabolic curve regression as stipulated by the International Convention 
on Load Lines. Additionally, with some corrections concerning $\mathrm{D}, \mathrm{C}_{\mathrm{B}}$, sheer profile, and superstructure sufficient length need is accounted for (IMO, 2005b).

Ship's transverse stability is a function of the metacentric height, estimated based on the vertical position of the centre of mass and buoyancy and metacentric radius. A parametric model, based on a geometric description of the ship hull, is used for estimating the position of the centre of buoyancy and metacentric radius. The metacentric height is calculated based on the second moment of area of the ship design water plane. As for the centre of mass calculation, the vertical position of the main weight items must be estimated beforehand.

Early estimates of motions natural frequencies can be made for the three natural frequencies in roll, heave, and pitch based only upon the main characteristics and parameters of the vessel (DnV, 2010), and manoeuvrability acceptance is performed based on the criteria developed in (Barr et al., 1981). The seakeeping operability criteria have been analysed in (Nordenstrom, 1971, Hutchison, 1981, Naito et al., 2006, Ghaemi and Olszewski, 2017) and recently in (Garbatov et al., 2019).

The energy efficiency design index, EEDI reference is defined based on the method suggested in (MEPC, 2011) and its required value as stipulated in (MEPC, 2012, 2018), which is adjusted by a reduction factor relative to EEDI baseline, concerning the Phase 2, 1 Jan 2020 to 31 Dec 2024 as a function of the main and auxiliary engine power, deadweight and service speed.

The estimation of the initial investment cost, CAPEX is based on design parameters such as ship size, weight, propulsion power, etc. This analysis uses a relationship between the input variables and the cost that is historically determined through the regression analysis (Benford, 1967).

The cost estimation relationships depend on one or more independent cost-driving variables, which can be the main dimensions of the ship, performance characteristics, or others. The data collected over time may be treated by the regression analysis to identify the most suitable function for the purpose. The output of this analysis is the most expected trend.

An essential step in the ship design is the trade route analysis, which is a condition of a restricted draught to define the cargo availability and the necessary fuel oil etc. and the total annual operation cost.

Once a ship completes the service life, the ship needs to be removed from operation, and the associated decommissioning cost needs to be included in the discounted life-cycle cash flow.

In this work, a conceptual ship design based on the quantitative risk-based life cycle integrity assessment of a ship in operation is performed. The ship system is formulated as a compromise decision support problem with multiple goal constraints to find the main dimensions of the ship.

Two models in the concept design, related to the ship and voyage descriptions, are typically accounted for (Damyanliev et al., 2017, Damyanliev et al., 2018). The first model includes the main ship dimensions, hull form generation, hydrostatics, free-board, resistance, propulsion, energy efficiency, lightship weight, cargo capacity, stability, and capital and decommissioning cost. The voyage model includes port sequence, voyage legs data, port/terminal data, cargo handled/port, round trip time/cost, annual cargo, and operational cost. The design solution has to satisfy the constraints related to entire ship systems.

The total cost of the ship is derived based on the annual operating cost, capital cost, and decommissioning cost, where the first is the sum of the salary of crew members, costs related to the stores and supplies, insurances, port expenses, and annual fuel cost, and the second one accounts for all costs of building the vessel. The required freight rate is estimated by dividing the discounted yearly average cost of the investment by the annual cargo capacity.

The concept design parametric model has been developed in (Hannapel and Vlahopoulos, 2010), and additionally, parametric models of free-board, seakeeping, and manoeuvrability are employed here. Three objective functions are defined to minimise the lightship weight and transportation cost and maximise the annual cargo income. The design governing parameters are presented in Table 1 and the constraints in Table 2. An additional constrain about the minimum engine power is included to guarantee the engine power is sufficient to perform satisfactory manoeuvring in severe weather conditions (Barr et al., 1981).

NSGA-II (Deb et al., 2002) is employed to ensure that the optimal solution can be obtained quickly with sufficient quantity and accuracy. Using the Pareto Frontier (Horn et al., 1994, Komuro, R. et al., 2006), which defines all optimal solutions represented in the design space, related to the 90 acceptable design solutions as a function of the lightship weight, annual cargo, and transportation cost are presented in the 3D diagram in Figure 2.

Table 1. Bulk carrier design governing parameters

\begin{tabular}{|c|c|c|c|}
\hline Decision Variables & Lower & Relations & Upper \\
\hline $\mathrm{L}(\mathrm{m})$ & 150.00 & $\leq \mathrm{L} \leq$ & 274.32 \\
\hline $\mathrm{B}(\mathrm{m})$ & 20.00 & $\leq \mathrm{B} \leq$ & 32.31 \\
\hline $\mathrm{D}(\mathrm{m})$ & 13.00 & $\leq \mathrm{D} \leq$ & 25.00 \\
\hline $\mathrm{T}(\mathrm{m})$ & 10.00 & $\leq \mathrm{T} \leq$ & 11.71 \\
\hline $\mathrm{C}_{\mathrm{b}}$ & 0.63 & $\leq \mathrm{C}_{\mathrm{b}} \leq$ & 0.75 \\
\hline $\mathrm{Vs}_{\mathrm{s}}$ knots $)$ & 8.00 & $\leq \mathrm{Vs} \leq$ & 16.00 \\
\hline
\end{tabular}


Table 2. Bulk carrier constraints

\begin{tabular}{|c|c|c|}
\hline Constraints & Description & Values \\
\hline $\mathrm{L} / \mathrm{B}$ & Greater & 5.0 \\
\hline $\mathrm{L} / \mathrm{D}$ & Lesser & 12.5 \\
\hline $\mathrm{L} / \mathrm{T}$ & Lesser & 24.0 \\
\hline Fn & Lesser & 0.32 \\
\hline DW (tonne) & Greater & 25,000 \\
\hline DW (tonne) & Lesser & 35,000 \\
\hline $\mathrm{T}-0.45 \cdot \mathrm{DW}^{0.31}$ & Lesser & 0.00 \\
\hline $\begin{array}{l}\mathrm{T}-0.7 \cdot \mathrm{D}-0.7 \\
(\mathrm{~m})\end{array}$ & Lesser & 0.00 \\
\hline $\begin{array}{ll}\begin{array}{l}\text { Engine } \\
(\mathrm{kW})\end{array} & \text { Power } \\
\end{array}$ & Greater & $\begin{array}{l}0.0763 \\
\mathrm{DW}+3.374\end{array}$ \\
\hline Stability & $\begin{array}{l}\text { To be } \\
\text { satisfied }\end{array}$ & \\
\hline Free-board & $\begin{array}{l}\text { To be } \\
\text { satisfied }\end{array}$ & \\
\hline Seakeeping & $\begin{array}{l}\text { To be } \\
\text { satisfied }\end{array}$ & \\
\hline Manoeuvrability & $\begin{array}{l}\text { To be } \\
\text { satisfied }\end{array}$ & \\
\hline
\end{tabular}

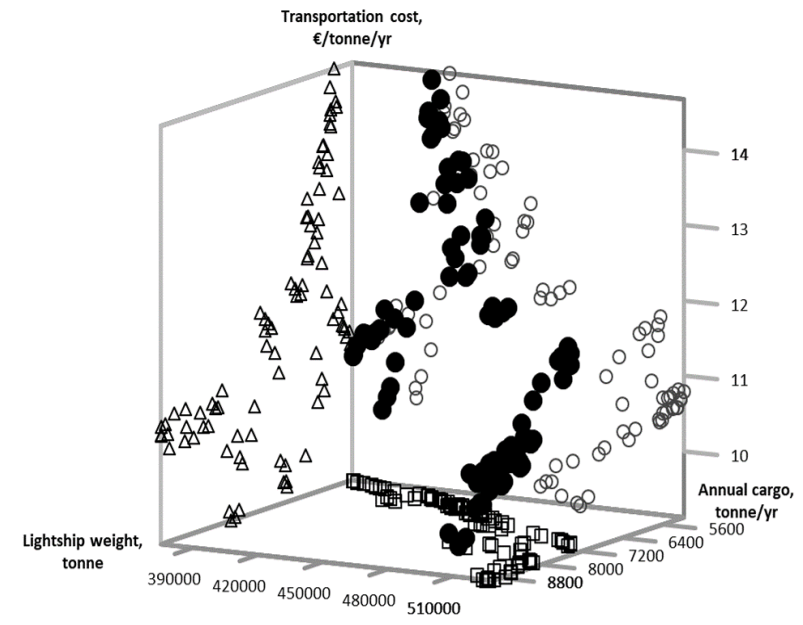

Figure 2 Pareto frontier of acceptable design solutions.

The triangular symbols in Figure 2 present the relationship between lightship weight and transportation cost. The circle represents the relationship between the annual cargo and transportation costs. The rectangular symbols represent the relationship between the annual cargo and lightship weight, and the solid circles represent the 3D relationship between the three variables.

As can be seen from Figure 3, for all acceptable design solutions were presented in Figure 2, the relatively longer ships are showing a lower level of EEDI, which can be explained by the fact that the slender hull form creates a lower resistance. By increasing the draught, the EEDI also decreases. The increasing of the speed is highly sensitive to the EEDI since the required power is in direct function of the service speed. Reducing the service speed may reduce the EEDI, but this is conditional on the manoeuvrability capacity of the ship.

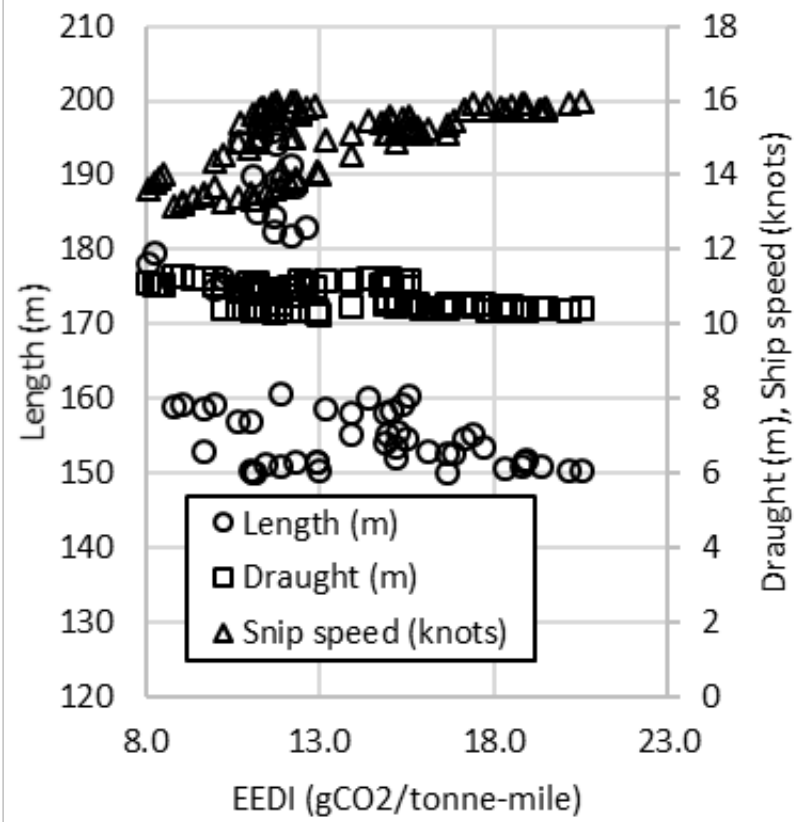

Figure 3 Length, draught, and ship speed as a function of EEDI.

\section{HAZARD DEFINITION}

The ship systems are exposed to various hazards that undermine the ship integrity during the service life. The most critical hazards experienced by ships operating in the open sea include extreme sea wave-induced load, still water load, continuous loading and unloading, capsizing, unacceptable seakeeping conditions, lack of manoeuvrability, structural collapse, and other hazards that may result from accidental loads, such as grounding, collision, fire or blast and improper cargo securing.

The lack of ship stability and structural collapse are identified as initiating events of failure. The risk-based ship integrity assessment transforms these initiating events into a risk measure, where all possible outcomes for the ship systems are evaluated.

The design governing parameters $\mathrm{L}, \mathrm{B}, \mathrm{D}, \mathrm{T}, \mathrm{C}_{\mathrm{b}}$, and $\mathrm{V}_{\mathrm{s}}$, are employed as risk control options here, to allow the ship design to be modified realistically and to identify the effect on the integral ship system conceptual design.

The ship hull structural capacity is evaluated concerning the first yielding. The design modifications are performed by varying the main governing characteristics of the ship. The failure is associated with the structural collapse as a part of the limit state failure of the ship hull structure is defined as a sequence of the events related to the destruction of primary ship hull structures. The ship's transverse stability is evaluated through the metacentric height. A parametric model, based on a simplified 
geometric representation of the ship hull, is used for the estimation of the metacentric height. The failure is associated capsizing of the ship.

The consequences of the overall hull girder failure and lack of stability are defined by the possible human loss, loss of cargo, contamination with fuel, and lubricating oil.

\section{RELIABILITY ANALYSIS}

\subsection{TIME-DEPENDENT PROFILE}

The risk assessment is based on the lack of stability and first yielding collapse of the ship structure subjected to vertical still water and wave-induced bending moments. The probability of failure is magnified by corrosion degradation. The failure consequences are also timedependent due to the time-value of money.

Two limit states as a series system are specified based on the definition of the conditions under which the ship and hull structure may not be able to fulfil their functions. The stability of the ship is evaluated based on the metacentric height. The load-carrying capacity of the ship structure is evaluated using simplified design formulations assuming that the ship is modelled as a free-free beam subjected to the still water and wave-induced bending moments

The non-linear model (Garbatov et al., 2007) is used in the corrosion degradation modelling, where the corrosion depth as a function of time is defined as:

$d^{\mathrm{cd}}(t)=d_{\infty} \cdot\left[1-\exp \left(-\left(t-\tau_{\mathrm{C}}\right) / \tau_{\mathrm{t}}\right], t>\tau_{\mathrm{C}}\right.$

$d^{\mathrm{cd}}(t)=0, t<\tau_{\mathrm{C}}$

where $\tau_{\mathrm{C}}$ is the coating life, and $\tau_{\mathrm{t}}$ is the transition life.

A time-dependent exponential model is used here to define the ship cost, $\mathrm{C}_{\text {ship }}(\mathrm{t})$ :

$$
\begin{aligned}
& C_{\text {ship }}(t)=\left\{C_{\text {ship }}\left(t_{\mathrm{o}}\right)-\left[C_{\text {ship }}\left(t_{\mathrm{o}}\right)-C_{\text {ship }}\left(t_{\mathrm{n}}\right)\right]\right\}\left\{1-\exp \left[-\left(t-\tau_{\text {ship } \mathrm{o}}\right) /\right.\right. \\
& \left.\left.\tau_{\text {ship }, \mathrm{t}}\right]\right\}, t>\tau_{\text {ship } \mathrm{o}} \\
& C_{\text {ship }}(t)=C_{\text {ship }}\left(t_{\mathrm{o}}\right), t<\tau_{\text {ship }, \mathrm{o}}
\end{aligned}
$$

where $\mathrm{C}_{\text {ship }}\left(\mathrm{t}_{\mathrm{o}}\right)$ is the initial ship cost, $\tau_{\text {ship, o }}$ is the time of permanent cost, and $\tau_{\text {ship }, t}$ is the transition time.

\subsection{RELIABILITY ESTIMATE}

Assessing the ship risk during the conceptual design phase may be performed based on the initial stability and first yielding limit state functions concerning the ship capsize and ship structural failure regarding the ship midship section.

The midship section modulus and the first yield capacity is estimated using the required midship section modulus $(Z)$ and permissible level of the yield stress $\left(\sigma_{\mathrm{p}}\right)$ of material as stipulated by the Classification Society Rules (DNV-GL, 2017).

The reliability of a ship system is defined as the probability of maintaining the ability to fulfil the design purpose for some period. The objective is to estimate the reliability based on its capacity when the demand acts upon the ship.

Two limit state functions are considered here related to the initial stability, $\mathrm{g}_{1}(\mathbf{X})$, and the first yielding collapse of the ship structure, $\mathrm{g}_{2}(\mathbf{X})$ as:

$g_{1}(\mathbf{X})=0.53 T-\left(0.085 C_{\mathrm{b}}-0.002\right) B^{2} / T / C_{\mathrm{b}}+1+0.52 D-0.07 B<0$

$g_{2}(\mathbf{X})=Z \cdot \sigma_{\mathrm{p}}-M_{\mathrm{SW}}-M_{\mathrm{W}}<0$

where $\mathrm{Z}$ is the midship section modulus, $\sigma_{\mathrm{p}}$ is the allowable yield stress, $M_{\mathrm{W}}$ is the vertical wave-induced bending moment, and $\mathrm{M}_{\mathrm{Sw}}$ is the still water bending moment.

The encountered design solutions for the involved variables are assumed as mean, values with a coefficient of variation of 0.05. Using the First Order Second Moment approach, the statistical descriptors of the limit state functions are defined, assuming that they are following to the Normal distribution function. The statistical descriptors of the vertical wave-induced bending moment are derived as defined in (Guedes Soares et al., 1996).

Failure will occur when any $\mathrm{g}_{\mathrm{i}}(\mathbf{X})$ fails, leading to $\mathrm{P}_{\mathrm{f}, \mathrm{i}}=\mathrm{P}\left(\mathrm{g}_{\mathrm{i}}(\mathbf{X})<0\right)$, which may be evaluated by using the standard normal distribution function as $\mathrm{P}_{\mathrm{f}, \mathrm{i}}=\mathrm{P}\left(\mathrm{M}_{\mathrm{i}}<0\right)=\Phi(-$ $\beta_{\mathrm{i}}$ ), where $\beta_{\mathrm{i}}$ is called reliability index (Cornell, 1969).

Considering the probability of failure of a series system of the two limit states, $\mathrm{P}_{\mathrm{f}}^{\mathrm{S}}$ each of which is modelled with a safety margin, $\mathrm{M}_{\mathrm{i}}$ :

$M_{\mathrm{i}}=g_{\mathrm{i}}(\mathbf{X}), i \in[1,2]$

The series system fails if just one of the limit state fails, defined as (Ditlevsen, 1979):

$P_{\mathrm{f}}^{\mathrm{S}}=-\Phi_{\mathrm{m}}(\boldsymbol{\beta} ; \rho)$

where $\Phi_{\mathrm{m}}$ is the m-dimensional normal distribution function and $\rho$ is the correlation coefficient between the two linearized safety margins.

A formal generalised series system beta reliability index, $\beta^{S}$ is given as:

$\beta^{\mathrm{S}}=\Phi^{-1}\left(P_{\mathrm{f}}^{\mathrm{S}}\right)$

The corrosion degradation is modelled as a non-linear time-dependent one (see Eqn 1 and 2) and the time-variant reliability index, $\beta^{\mathrm{S}}(\mathrm{t})$ is assumed to follow the same trend, 
where $t \in\left[t_{0}, t_{n}\right]$ and $\beta^{S}(t)$ is defined as:

$\beta^{\mathrm{S}}(t)=\beta^{\mathrm{S}}\left(t_{\mathrm{o}}\right)-\left[\beta^{\mathrm{S}}\left(t_{\mathrm{o}}\right)-\beta^{\mathrm{S}}\left(t_{\mathrm{n}}\right)\right]\left\{1-\exp \left[-\left(t-\tau_{\mathrm{C}}\right) / \tau_{\mathrm{t}}\right]\right\}, t>\tau_{\mathrm{C}}(10)$

$\beta^{\mathrm{S}}(t)=\beta^{\mathrm{S}}\left(t_{0}\right), t<\tau_{\mathrm{C}}$

\section{RISK-BASED DESIGN}

The uncertainties associated with the collapse of the ship system, potential losses resulting from the ship collapse, which is expressed as a probability of failure, $\mathrm{P}_{\mathrm{f}, \mathrm{j}} \mathrm{S}$ are accounted for in the risk assessment. The probability of failure is described as a numeric value, and the consequences, $\mathrm{C}_{\mathrm{f}, \mathrm{j}}$ are in monetary value:

$\operatorname{Risk}\left(t_{\mathrm{n}}\right)=\Sigma_{\mathrm{j}} P_{\mathrm{f}, \mathrm{j}} \mathrm{S}\left\{P\left[g\left(\mathbf{X} \mid t_{\mathrm{j}}\right) \leq 0\right]\right\} C_{\mathrm{f}, \mathrm{j}}\left(\mathbf{X} \mid t_{\mathrm{j}}\right)$

where $\mathrm{P}_{\mathrm{f}, \mathrm{j}} \mathrm{S}\left\{\mathrm{P}\left[\mathrm{g}\left(\mathbf{X} \mid \mathrm{t}_{\mathrm{j}}\right) \leq 0\right]\right\}$ is the system probability of failure and $\mathrm{C}_{\mathrm{f}, \mathrm{j}}\left(\mathbf{X} \mid \mathrm{t}_{\mathrm{j}}\right)$ is the impact, which defines the consequence cost of failure, $\mathbf{X}$ is the vector of the involved parameters, and $t_{j} \in\left[t_{0}, t_{n}\right]$. The probability of failure of the ship is derived based on the system of limit states. The consequence costs include the design measures, loss of cargo, loss of the ship, accidental spill, and loss of human life and penalties due to do excessive air pollution will be defined here.

The ship's optimal safety level may be defined by employing a cost-benefit analysis, where the goal is to establish an acceptable safety and reliability level by using the risk control option in redesigning the initial ship's main dimensions. The cost-benefit analysis of the ship system is performed based on the total expected risk, $\operatorname{Risk}_{\text {total }}\left(t_{n} \mid \mathbf{X}, \beta^{\mathrm{S}}\right)$, which is a product of the probability of failure and consequence cost, defined as (Garbatov et al., 2018a, Huang and Garbatov, 2020):

$\operatorname{Risk}_{\text {total }}\left(t_{\mathrm{n}} \mid \mathbf{X}, \beta^{S}\right)=\operatorname{Ris} k_{\text {failure }}\left(t_{\mathrm{n}} \mid \mathbf{X}, \beta^{\mathrm{S}}\right)+\operatorname{Ris} k_{\text {measure }}\left(\mathbf{X}, \beta^{S}\right)$

where Risk $k_{\text {failure }}\left(t_{n} \mid \mathbf{X}, \beta^{S}\right)$ is the risk associated with the ship failure, and its consequence costs and $\operatorname{Risk}_{\text {measure }}\left(\mathbf{X}, \beta^{\mathrm{S}}\right)$ is the cost of the implemented ship safety measures in redesigning the ship. Both terms are defined as a function of the system reliability index, $\beta^{\mathrm{S}}$.

A decision can be made by analysing the cost associated with the loss of the ship, cargo, accidental spill, and human life and minimising the total expected risk, Risk failure $\left(\mathrm{t}_{\mathrm{n}} \mid \mathbf{X}\right.$, $\left.\beta^{\mathrm{S}}\right)$. The risk associated with the ship collapse is estimated on the base on the service life, accounting for the probability of system failure and the discount rate of $\gamma$ as a function of $\mathbf{X}, \beta^{\mathrm{S}}$, and time as:

$$
\begin{aligned}
& \operatorname{Risk}_{\text {failure }}\left(t_{\mathrm{n}} \mid \mathbf{X}, \beta^{\mathrm{S}}\right)=\Sigma_{\mathrm{j}}^{\mathrm{n}}\left\{P _ { \mathrm { f } } ( t _ { \mathrm { j } } | \mathbf { X } , \beta ^ { \mathrm { S } } ) \cdot \left[C_{\text {resale }}\left(t_{\mathrm{j}} \mid \mathbf{X}, \beta^{\mathrm{S}}\right)+C_{\text {cargo }}+\right.\right. \\
& \left.C_{\text {spill, air }}+C_{\text {human }}\right] \exp \left(-\gamma t_{\mathrm{j}}\right\}
\end{aligned}
$$

where $\mathrm{P}_{\mathrm{f}}\left(\mathrm{t}_{\mathrm{j}} \mid \mathbf{X}, \beta^{\mathrm{S}}\right)$ is the probability of failure, $\mathrm{C}_{\text {resale }}\left(\mathrm{t}_{\mathrm{j}} \mid \mathbf{X}\right.$, $\beta^{S}$ ) is the resale cost of the ship in the year $t_{j}, C_{\text {cargo }}$ is the cost associated with the loss of cargo, $\mathrm{C}_{\text {spill, air }}$ is the cost of the accidental spill and penalties due to air pollution, $\mathrm{C}_{\text {human }}$ is the cost associated with the loss of human life and $\gamma$ is the discount rate.

The cost of the ship resale, $C_{\text {resale }}\left(t_{j} \mid \mathbf{X}, \beta^{S}\right)$ at any time $t_{j}$ is defined as a function of the initial resale value of the ship at $t_{0}=0$ year, and the scraping value at the $t_{n}$ year, estimated as:

$$
\begin{aligned}
& C_{\text {resale }}\left(t_{\mathrm{j}} \mid \mathbf{X}, \beta^{\mathrm{S}}\right)=C_{\text {ship }}(t)=\left\{C_{\text {ship }}\left(t_{\mathrm{o}}\right)-\left[C_{\text {ship }}\left(t_{\mathrm{o}}\right)-C_{\text {ship }}\left(t_{\mathrm{n}}\right)\right]\right\} \cdot\{1- \\
& \exp \left[-\left(t-\tau_{\text {ship }, \mathrm{o}}\right) / \tau_{\text {ship }, t]\}, t>\tau_{\text {ship }, \mathrm{o}}}\right. \\
& C_{\text {resale }}\left(t_{\mathrm{j}} \mid \mathbf{X}, \beta^{\mathrm{S}}\right)=C_{\text {ship }}(t)=C_{\text {ship }}\left(t_{\mathrm{o}}\right), t<\tau_{\text {ship }, \mathrm{o}}
\end{aligned}
$$

where $t_{j}$ is the year of the operation, $t_{j} \in\left[t_{o}, t_{n}\right]$ (Figure 4).

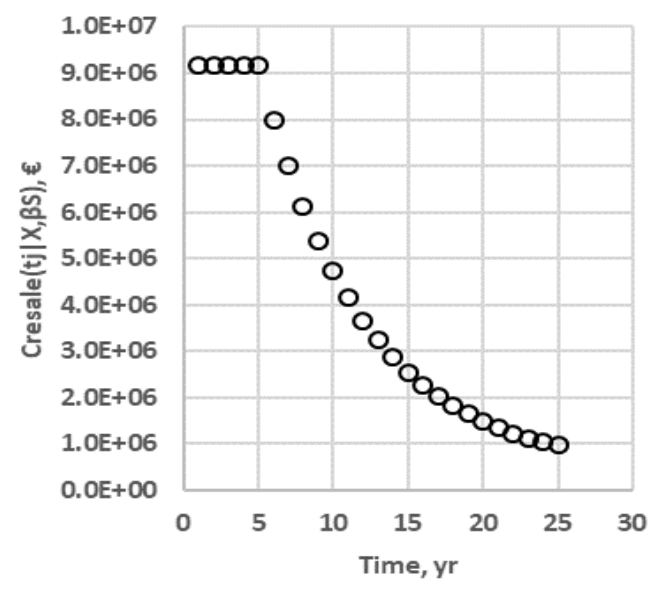

Figure 4 Ship resale cost as a function of time.

The cost of the loss of cargo, $\mathrm{C}_{\text {cargo }}$ is estimated assuming that a part of the cargo, $\mathrm{P}_{\text {cargo }}$ is lost in the case of ship collapse, defined as:

$C_{\text {cargo }}\left(\mathbf{X}, \beta^{S}\right)=C_{\text {cargo/tonne }} f_{\text {cargo }} P_{\text {cargo }}\left(\mathbf{X}, \beta^{S}\right)$

where $\mathrm{C}_{\text {cargo/tonne }}$ is the cost of a tonne of cargo and $\mathrm{f}_{\text {cargo, }}$, is the percentage of cargo lost (Figure 5).

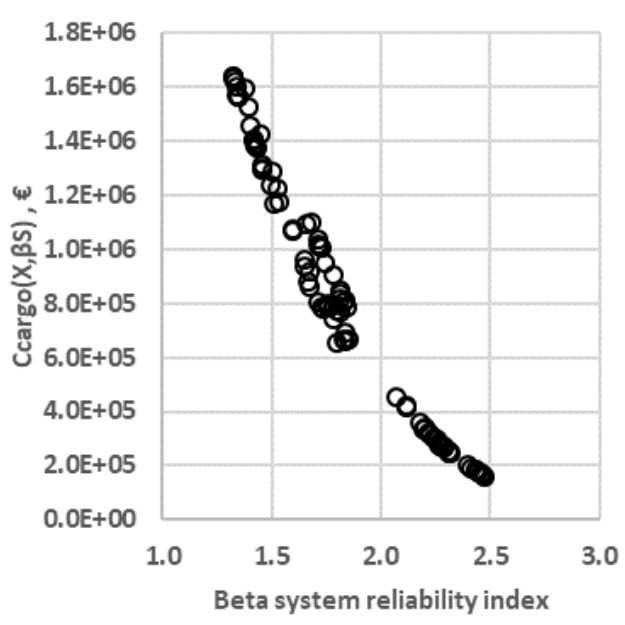

Figure 5 Cost of loss of cargo. 
In the case of ship collapse, apart, $f_{\text {spill }}$ of the total amount of oil and fuel, $\mathrm{P}_{\text {fuel carried }}$ may be spilt, and $\mathrm{f}_{\text {shore }}$ is the probability of the amount of spill reaching the shoreline (Sørgard et al., 1999). The weight of discharge that needs to be cleaned up is defined as $\mathrm{f}_{\text {spill }} \mathrm{f}_{\text {shore }} \mathrm{P}_{\text {fuel carried, and the }}$ cost, $\mathrm{C}_{\text {spill }}$ associated with that is:

$$
C_{\text {spill }}\left(\mathbf{X}, \beta^{S}\right)=f_{\text {spill }} f_{\text {shore }} C_{\text {ATS }} P_{\text {fuel carried }}\left(\mathbf{X}, \beta^{S}\right)
$$

where $C_{\mathrm{ATS}}$ is the cost of one-tonne accidentally spilt oil and fuel that needs to be cleaned (Figure 6).

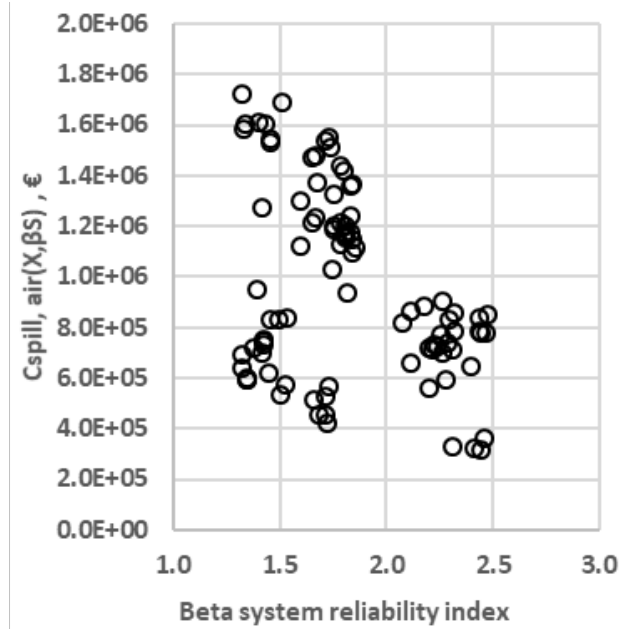

Figure 6 Cost of fuel and oil spill cleaning and air pollution penalty.

The cost associated with the fatality is based on the Implied Cost of Avoiding a Fatality (ICAF), which uses a risk model obtained from the average of the OCDE countries (OCDE, 2014). The cost of loss of human life here is defined as given in (Horte et al., 2007):

$C_{\text {human }}\left(\mathbf{X}, \beta^{\mathrm{S}}\right)=n_{\text {crew }}\left(\mathbf{X}, \beta^{\mathrm{S}}\right) f_{\text {crew }} \mathrm{ICAF}$

where $\mathrm{n}_{\text {crew }}$ is the number of crew members, $\mathrm{f}_{\text {crew }}$ is the probability of loss of human life (Figure 7).

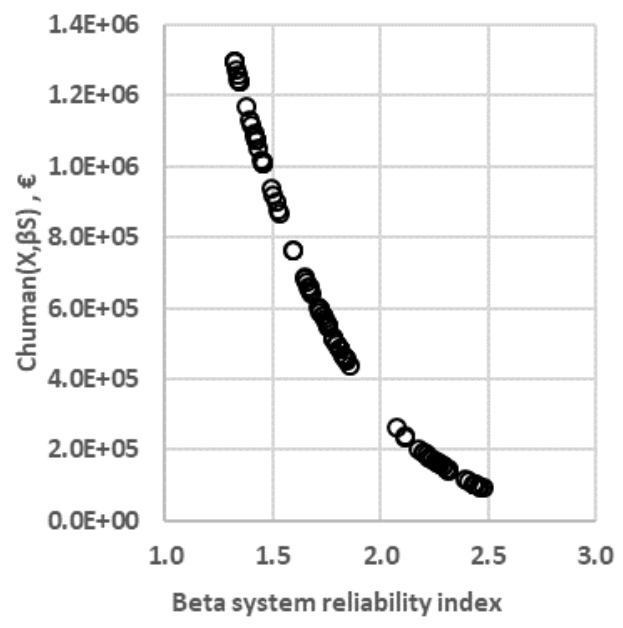

Figure 7 Cost of human loss.
In the case of air pollution, EEDI can be measured by the EEDI reference (MEPC, 2011, 2018):

$\mathrm{EEDI}_{\mathrm{ref}}=a b^{-\mathrm{c}}, \mathrm{gCO}_{2} /$ tonne-mile

where for a bulker ship $\mathrm{a}=961.79, \mathrm{~b}=\mathrm{DWT}, \mathrm{c}=-0.47$.

Furthermore, the required $\mathrm{EEDI}_{\text {req }}$ may be recalculated as (MEPC, 2012, 2018):

$\mathrm{EEDI}_{\text {req }}=(1-X / 100) \mathrm{EEDI}_{\text {ref }}$

where $\mathrm{X}$ is a reduction factor relative to EEDI baseline, which in the case of a bulk carrier of 20,000 DWT and above, Phase 2, 1 Jan 2020 to 31 Dec 2024 for 2020 is $\mathrm{X}=20, \mathrm{EEDI}_{r e f}=\mathrm{EEDI}\left(\mathbf{X}, \beta^{\mathrm{S}}\right)$ can be estimated as a function of the main and auxiliary engine power, deadweight and service speed as:

$\operatorname{EEDI}\left(\mathbf{X}, \beta^{\mathrm{S}}\right)=3.114\left(190 P_{\mathrm{w}, \mathrm{me}}+215 P_{\mathrm{w}, \mathrm{ae}}\right) / D W / V_{\mathrm{s}}$

where $\mathrm{P}_{w}$, me is the power of the main engine, and $\mathrm{P}_{\mathrm{w}}$, ae is the power of the auxiliary engines.

The penalty for air pollution in a monetary unit, $\mathrm{C}_{\mathrm{air}}$ pen $(\mathbf{X}$, $\left.\beta^{S}\right)$ is based on the fact that EEDI of the ship engine complex is greater than $\mathrm{EEDI}_{\text {req, }}$ and it is defined as:

$C_{\text {air pen }}\left(\mathbf{X}, \beta^{\mathrm{S}}\right)=\left[\mathrm{EEDI}_{\mathrm{req}}-\operatorname{EEDI}\left(\mathbf{X}, \beta^{\mathrm{S}}\right)\right] C_{\text {EEDIpen }}$ when $\operatorname{EEDI}\left(\mathbf{X}, \beta^{\mathrm{S}}\right)>\operatorname{EEDI}_{\text {req }}$

where $\mathrm{C}_{\text {EEDIpen }}$ is the penalty for air pollution of one $\mathrm{gCO}_{2}$ /tonne-mile above $\mathrm{EEDI}_{\mathrm{req}}$. associated with the reliability level, $\beta_{0} \mathrm{~S}$.

The cost of enhancing safety by redesign the ship varying the main dimensions, including the cost of material and labour may result in a positive or negative value, respectively:

$\operatorname{Risk}_{\text {measure }}\left(t_{\mathrm{j}}=t_{\mathrm{o}} \mid \mathbf{X}, \beta^{\mathrm{S}}\right)=C_{\text {ship }}\left(t_{\mathrm{j}}=t_{\mathrm{o}} \mid \mathbf{X}, \beta^{\mathrm{S}}\right)-C_{\text {ship }}\left(t_{\mathrm{j}}=t_{\mathrm{o}} \mid \mathbf{X}, \beta_{\mathrm{o}}^{\mathrm{S}}\right)$

where $C_{\text {ship }}\left(t_{j}=t_{0} \mid \mathbf{X}, \beta_{o}{ }^{S}\right)$ is the cost of the ship associated with the reliability level, $\beta_{0}$ s.

The estimated beta reliability index is compared to an accepted target level, which depends on different factors, as reported by Moan, (1998). It may vary from one industry to another, depending on the seriousness of its consequence, or public and media sensitivity. Appropriate values of target safety and reliability are not readily available and are usually determined by surveys or by examinations of the statistics on failures. However, the fundamental difference between a risk assessment and a reliability analysis needs to be acknowledged when interpreting such results.

The target level adapted here is related to failure cause and mode. Paik and Frieze, (2001) studied the reliability index 
for different ships, including bulk carriers, and the presented annual beta reliability index is of $\beta_{1}=2.2$.

Considering a reference period, $\mathrm{t}_{\mathrm{r}}$ equal to the service life, the beta target reliability level, $\beta_{\text {target }}\left(\mathrm{t}_{\mathrm{r}}\right)$, corresponding to an arbitrary service life can be derived based on the annual Beta reliability index, $\beta_{1}$ as:

$\beta_{\text {target }}\left(t_{\mathrm{r}}\right)=\Phi^{-1}\left\{\left[\Phi\left(\beta_{1}\right)\right]^{\mathrm{tr}}\right\}$

A more detailed recommendation is provided in (ISO 2394 1998) where the beta target reliability index is given for the service life and related not only to the consequences but also to the relative costs of safety measures, see also for an example in (Garbatov et al., 2018a).

In the present analysis, the estimated beta system reliability index for all design solutions, more significant than the target reliability index for the regular operation of the bulk carrier as defined in the present study of $\beta_{1 \mathrm{~s}}=2.31$ are possible solutions as can be seen in Figure 8.

The required EEDI, adjusted to be used after 2020, is 5.3 $\mathrm{gCO}_{2} /$ tonne-mile for the bulk carrier ships. The optimal risk-based design solution is No 3 as can be seen in Figure 8 and its descriptors in Table 3 . The encountered design solution does not involve any enhancement of the propulsion system and any engineering solution in reducing the $\mathrm{gCO}_{2}$ /tonne-mile.

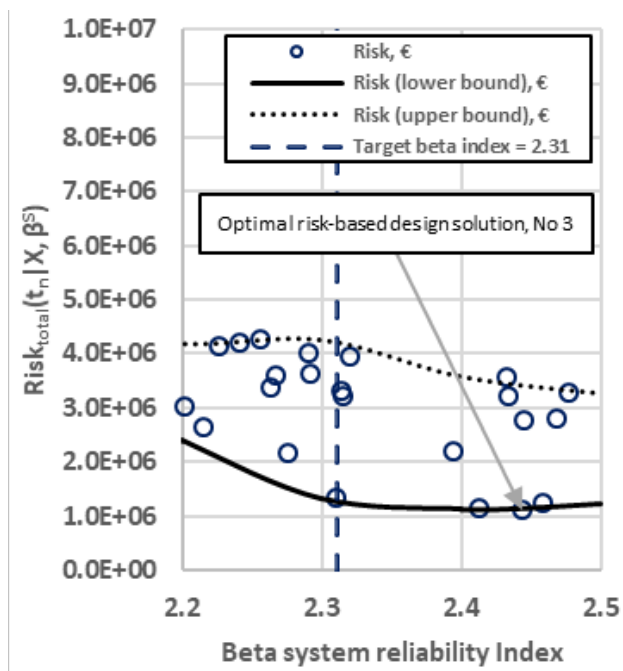

Figure 8 Optimal risk-based design solution, No 3, $\mathrm{EEDI}=7.9 \mathrm{gCO}_{2} /$ tonne-mile $\mathrm{Vs}=13.55$ knots

For this particular ship design solution, No 3, some measures, including the hull lines optimisation, main engine and propeller alternatives, energy-saving devices and rudder arrangement are needed.
Table 3 Ship characteristics of optimal risk-based design solution, No 3

\begin{tabular}{|l|l|l|l|}
\hline $\mathrm{L}, \mathrm{m}$ & 179.1 & $\mathrm{~L} / \mathrm{B}$ & 5.82 \\
\hline $\mathrm{B}, \mathrm{m}$ & 32.08 & $\mathrm{~L} / \mathrm{D}$ & 12.06 \\
\hline $\mathrm{D}, \mathrm{m}$ & 14.84 & $\mathrm{~L} / \mathrm{T}$ & 16.15 \\
\hline $\mathrm{T}, \mathrm{m}$ & 11.08 & $\mathrm{Fn}$ & 0.166 \\
\hline $\mathrm{C}_{\mathrm{B}}$ & 0.65 & $\mathrm{LW}$, tonne & 7,580 \\
\hline $\mathrm{Vs}, \mathrm{kn}$ & 13.55 & $\mathrm{AC},($ tonne/yr) & 479,964 \\
\hline $\mathrm{DW}$, tonne & 34,926 & $\mathrm{TC},(€ /$ tonne) & 9.12 \\
\hline
\end{tabular}

\section{ENERGY-EFFICIENT SHIP DESIGN SOLUTIONS}

Several possible paths can be followed in reducing the EEDI. An energy-efficient ship of 35,000 DWT, a handy-size bulk carrier optimised to meet the 2020 EEDI requirements and put into operation in 2008 was presented in (Minchev et al., 2013). The measures include the hull lines optimisation, main engine and propeller alternatives studies, energy-saving devices, and rudder arrangement study.

A further analysis of ship design affecting EEDI has been presented in (OECD, 2017) highlighting four design parameters that can influence the desired index level. These parameters are the Admiralty coefficient that gives the approximate relationships between the needed propulsion power, ship speed and displacement, specific fuel oil consumption (SFOC), LW/LBD relation, and ship design speed. SFOC for the last 20 years is in the range of 165 to $180 \mathrm{~g} / \mathrm{KWh}$ and depends on the development of machinery technology.

The speed reduction has a more significant impact on the EEDI. However, the considerable reduction of installed power and the speed could conflict with the minimum propulsion power to maintain the manoeuvrability of the ship in adverse conditions.

During the years, many different energy-saving devices have been studied to correct the energy performance of the ship like the post swirl fins, rudder bulb, Kappel propeller design, propeller boss cap fins; AHT nozzle, Mewis duct, pre swirl fins, and different efficiency rudders. In a combination of some of them, it is possible to increase the propulsion system efficiency by up to 10 $\%$ as was demonstrated in (de Kat and Mouawad, 2019, MAN, 2020).

One possible way of complying with the required EEDI, Phase 1, 2, or 3 is by installing a hybrid electrical system, The installation of the hybrid propulsion system permitted the lowering of the EEDI level and introduces additional benefits as enabling cold ironing, eliminating frequent load variations, power redundancy, reduction of local and global emissions and less noise and vibrations (Jeong et al., 2018, Wang et al., 2018). 


\section{CONCLUSIONS}

The study evaluated the risk-based ship design of a bulk carrier accounting for EEDI. The effect of EEDI was based on hull form, resistance and propulsion, weights, initial stability, freeboard, seakeeping and manoeuvrability, as well as CAPEX, OPEX and DECEX. At concept stage, an optimal design solution was defined based on EEDI, shipbuilding, operation, and resale costs at the end of the service life, as an input variable in the risk estimate.

Using a classical ship design approach appropriate to bulk carriers, the IMO stipulated maximum required EEDI may lie below the estimated for the particular ship, and one of the reasons may be inappropriate engine selection, hull form, unacceptable service, type, and fuel consumption. Finally, several possible solutions for reducing the effects of $\mathrm{CO}_{2}$ emission have been considered, including propulsion power, ship speed and displacement, specific fuel oil consumption, LW/LBD relation, and ship design speed.

The method of multi-objective mathematical optimisation is considered a valuable tool that may enhance the quality of the conceptual design solution by accounting for naval architectural design aspects, reliability, and risk throughout the vessel's life-cycle.

\section{ACKNOWLEDGEMENTS}

This work has been performed within the project NP8/2020 - Conceptual Design of Ships Minimizing the Risk of Environmental Pollution and was funded by the State budget through the TU Varna Research Programme under contract No 108/22.05.2020.

\section{REFERENCES}

1. BARR, R. A., MILLER, E. R., ANKUDINOV, V. and LEE, F. C., (1981), Technical basis for manoeuvring performance standards, Hydronautics Inc Laurel MD, Final rept. Sep 80Dec 81.

2. BENFORD, H., (1967), The Practical Application of Economics of Merchant Ship Design, Journal of Marine Technology, The Society of Naval Architecture and Marine Engineering, 519-536.

3. BERGSTRÖM, M., ERIKSTAD, S. O. and EHLERS, S., (2016), Assessment of the applicability of goal- and risk-based design on Arctic sea transport systems, Ocean Engineering, 128, 183-198.

4. BLASCO, J., DURAN-GRADOS, V., HAMPEL, M. and MORENO-GUTIERREZ, J., (2014), Towards an integrated environmental risk assessment of emissions from ships' propulsion systems, Environ Int, 66, 44-47.
5. BOUlOUGOURIS, E., PAPANIKOLAOU, A. and PAVLOU, A., (2011), Energy efficiency parametric design tool in the framework of holistic ship design optimization, Proceedings of the Institution of Mechanical Engineers, Part M: Journal of Engineering for the Maritime Environment, 225, (3), 242-260.

6. CARLTON, J. S., (1994), Marine Propellers and Propulsion, Elsevier, Burlington, USA

7. CORNELL, C., (1969), A Probability-Based Structural Code, Journal of American Concrete Institute Journal, 66(12), 974-985.

8. CUDINA, P., ZANIC, V. and PREBERG, P., (2010), Multiattribute Decision Making Methodology in the Concept Design of Tankers and Bulk-Carriers, Proceedings of the $11^{\text {th }}$ Symposium on Practical Design of Ships and Other Floating Structures, PRADS, 19.24.09.2010., Rio de Janeiro; Brazil.

9. DAMYANLIEV, T., GEORGIEV, P., ATANASOVA, I. and GARBATOV, Y., (2018), Conceptual design of multipurpose ship and fleet accounting for SME shipyard building limitations Progress in Maritime Technology and Engineering, C. Guedes Soares and T. A. Santos, London, Taylor \& Francis Group, 317-324.

10. DAMYANLIEV, T. P., GEORGIEV, P. and GARBATOV, Y., (2017), Conceptual ship design framework for designing new commercial ships, Progress in the Analysis and Design of Marine Structures, C. Guedes Soares and Y. Garbatov, London, Taylor \& Francis Group, 183-191.

11. DE KAT, J. O. and MOUAWAD, J., (2019), Green Ship Technologies, Sustainable Shipping, 33-92.

12. DEB, K., PRATAP, A., AGRAWAL, S. and MEYARIVAN, T., (2002), A Fast and Elitist Multi-objective Genetic Algorithm: NSGA-II, IEEE Transactions on Evolutionary Computation, 6(2), 182-197.

13. DITLEVSEN, O., (1979), Narrow reliability bounds for structural systems, Journal of Structural Mechanics, 7(4), 453-472.

14. DNV-GL, (2017), DNVGL-RU-9111:2015-7, Rules for Classification, Oslo, DNV GL.

15. DNV, (2010), Rules for classification of ships, Common structural rules for bulk carriers with length 90 meters and above, Høvik, Norway, DET NORSKE VERITAS, 8.

16. GARBATOV, Y., ALMANY, N. and TEKGOZ, M., (2019), Operational Behaviour of an Offshore Multipurpose Support Vessel in the Eastern Mediterranean Sea, International Journal of Maritime Engineering, 161(A3), A303-A312.

17. GARBATOV, Y., GUEDES SOARES, C. and WANG, G., (2007), Nonlinear Time-Dependent Corrosion Wastage of Deck Plates of Ballast and Cargo Tanks of Tankers, Journal of Offshore 
Mechanics and Arctic Engineering, 129(1), 4855.

18. GARBATOV, Y., SISCI, F. and VENTURA, M., (2018a), Risk-based framework for ship and structural design accounting for maintenance planning, Ocean Engineering, 166, 12-25.

19. GARBATOV, Y., VENTURA, M., GUEDES SOARES, C., GEORGIEV, P., KOCH, T. and ATANASOVA, I., (2018b), Framework for conceptual ship design accounting for risk-based life cycle assessment, Maritime Transportation and Harvesting of Sea Resources, C. Guedes Soares and A. Teixeira, London, Taylor \& Francis Group, 921-931.

20. GHAEMI, M. H. and OLSZEWSKI, H., (2017), Total ship operability - review, concept and criteria, Polish maritime research, 24(93), 74-81.

21. GUEDES SOARES, C., DOGLIANI, M., OSTERGAARD, C., PARMENTIER, G. and PEDERSEN, P. T., (1996), Reliability-Based Ship Structural Design, Transactions of the Society of Naval Architects and Marine Engineers (SNAME), 104, 359-389.

22. HANNAPEL, S. and VLAHOPOULOS, N., (2010), Robust and Reliable Multidiscipline Ship Design, Proceedings of the 13th AIAA/ISSMO Multidisciplinary Analysis Optimization Conference, AIAA 2010-9394 Fort Worth, Texas.

23. HOLTROP, J. and MENNEN, G. G. J., (1982), An approximate power prediction, International Shipbuilding Progress, 29, 166 - 170.

24. HORN, J., NAFPLIOTIS, N. and GOLDBERG, D., (1994), A niched Pareto genetic algorithm for multiobjective optimisation, IEEE World Congress on Computational Intelligence, 1, 8287.

25. HORTE, T., WANG, W. and WHITE, N., (2007), Calibration of the hull girder ultimate capacity criterion for double-hull tankers, Proceedings of the 10th International Symposium on Practical Design of Ships and Other Floating Structures (PRADS), Houston, USA, 235-246.

26. HUANG, Y. C. and GARBATOV, Y., (2020), Multiobjective Reliability-Based Design of Ship Structures Subjected to Fatigue Damage and Compressive Collapse, Journal of Offshore Mechanics and Arctic Engineering, 142(5), 051701.

27. HUTCHISON, B. L., (1981), Risk and Operability analysis in the marine environment, SNAME Transactions, 89, 127-154.

28. IMO, (2002), Consolidated text of the guidelines for formal safety assessment (FSA) for use in the IMO rule-making process, MSC/Circ.1023 /MEPC/ Circ.392, 4 Albert Embankment, London SE1 7SR, International Maritime Organization Publishing.
29. IMO, (2005a), Amendments to the guidelines for formal safety assessment (FSA) for use in the IMO rule-making process, MSC/Circ.1180MEPC/Circ.474, 4 Albert Embankment, London SE1 7SR, International Maritime Organization Publishing.

30. IMO, (2005b), International Convention on Load Lines, 1966 and Protocol of 1988, as amended in 2003, Consolidated Edition, 4 Albert Embankment, London SE1 7SR, International Maritime Organization Publishing.

31. IMO, (2008), Formal safety assessment on crude oil tankers, 4 Albert Embankment, London SE1 7SR, International Maritime Organization Publishing.

32. IMO, (2013), Revised guidelines for formal safety assessment (FSA) for use in the IMO rulemaking process, MSC-MEPC.2/Circ.12, 4 Albert Embankment, London SE1 7SR, International Maritime Organization Publishing.

33. ITTC (1978). "ITTC Performance Prediction Method." from http://ittc.sname.org/2002 recomm proc/7.5-02-03-01.4.pdf.

34. JEONG, B., OGUZ, E., WANG, H. and ZHOU, P., (2018), Multi-criteria decision-making for marine propulsion: Hybrid, diesel-electric and diesel mechanical systems from costenvironment-risk perspectives, Applied Energy, 230, 1065-1081.

35. KEANE, A. J., PRICE, W. G. and SCHACHTER, R. D., (1991), Optimization Techniques In Ship Concept Design, Transaction of the Royal Institute of Naval Architecture, A.133, 123-129.

36. KOMURO, R., FORD, E. D. and REYNOLDS, J. H., (2006), The use of multi-criteria assessment in developing a process model, Ecological Modelling, 197(3), 320-330.

37. KUPRAS, L. K., (1976), Optimisation Method and Parametric Design in Precontracted Ship Design, International Shipbuilding Progress, 23, 138-155.

38. LAMB, T., (2003) Ship Design and Construction, Society of Naval Architects and Marine Engineers, US.

39. LEE, K. H., KIM, K. S., LEE, J. H., PARK, J. H., KIM, D. G. and KIM, D. S., (2007), Development of Enhanced Data Mining System to Approximate Empirical Formula for Ship Design, Springer Berlin / Heidelberg.

40. LINDSTAD, E. and BØA, T. I., (2018), Potential power setups, fuels and hull designs capable of satisfying future EEDI requirements, Transportation Research Part D, 276-290.

41. LYON, T. and MISTREE, F., (1985), $A$ Computer-based Method for the Preliminary Design of Ships, Journal of Ship Research, 29(4), 251-269.

42. MAN (2020). "MAN Diesel \& Turbo, Energy Efficiency Design Index." 2020. 
43. MEPC, (2011), Amendments to the annex of the protocol of 1997 to amend the International Convention for the prevention of pollution from ships, 1973, as modified by the protocol of 1978 relating thereto MEPC 203(62), The Marine Environment Protection Committee (MEPC).

44. MEPC, (2012), Guidelines for Calculation of Reference Lines for use with the Energy Efficiency Design Index (EEDI) MEPC 215(63), Marine Environment Protection Agency (MEPC).

45. MEPC, (2018), Resolution MEPC.301(72) Amendments to MARPOL Annex VI (ECAs and required EEDI for ro-ro cargo ships and ro-ro passenger ships, The Marine Environment Protection Committee (MEPC), MEPC.308(73)19/Add.1.

46. MESSAC, A. and MULLUR, A. A., (2007), Multiobjective optimization: Concepts and methods, Optimization of structural and mechanical systems, J. Arora, World Scientific, 121-147.

47. MINCHEV, A., SCHMIDT, M. and SCHNACK, S., (2013), Contemporary Bulk Carrier Design to Meet IMO EEDI Requirements. Launceston, Third International Symposium on Marine Propulsors, Tasmania.

48. MOAN, T., (1998), Target levels for structural reliability and risk analyses of offshore structures, Risk and reliability in marine technology, C. Guedes Soares, Rotterdam, A.A. Balkema, 351-368.

49. NAITO, S., MINOURA, M., HAMANAKA, S. and YAMAMOTO, T., (2006), Long -term International Shipbuilding Progress, 53(3), 229252.

50. NORDENSTROM, N., (1971), Methods for Predicting Long-Term Distributions of Wave Loads and Probability of Failure for Ships, Report $\mathrm{N}^{\circ}$ 71-2-S, Det Norske Veritas.

51. NOWACKI, H., (2019), On the History of Ship Design for the Life Cycle, A Holistic Approach to Ship Design., A. Papanikolaou, Athens, Springer, 43-74.

52. OCDE, (2014), OCDE Factbook-Economic, Environmental and Social Statistics, 96-106.

53. OECD, (2017), Analysis of selected measures promoting the construction and operation of greener ships, s.l., Council Working Party on Shipbuilding (WP6).

54. PAIK, J. K. and FRIEZE, P. A., (2001), Ship structural safety and reliability, Prog Struct Engng Mater, 3, 198-210.

55. PAPADIMITRIOU, S., KOLIOUSIS , I. G., SDOUKOPOULOS, E., LYRIDIS, D. V., TSIOUMAS, V. and STAVROULAKIS, P. J., (2018), The Dynamics of Short Sea Shipping. New Practices and Trends, Cham, Switzerland, Palgrave Macmillan.
56. PAPANIKOLAOU, A. D., GUEDES SOARES, C., JASIONOWSKI, A., JENSEN, J. J., MCGEORGE, D., POYLIO, E. and VASSALOS, D., (2009), Risk-Based Ship Design, Springer.

57. PATUllO, R. N. M. and THOMSON, G. R., (1965), The BSRA Trawler Series Beam-Draught and Length-Displacement Ratio Series resistance and propulsion tests., RINA, 1 and 2.

58. PLESSAS, T., KANELLOPOULOU, A., ZARAPHONITIS, G., PAPANIKOLAOU, A. and SHIGUNOV, V., (2018), Exploration of design space and optimisation of RoPax vessels and Exploration of design space and optimisation of RoPax vessels and, Ocean Engineering, 162, 1-20.

59. RAO, S. S., 2009, Engineering optimization: theory and practice, John Wiley \& Sons.

60. SMITH, T., RAUCCI, C., HAJI HOSSEINLOO, S., ROJON, I., CALLEYA, J., DE LA FUENTE, S., WU, P. and PALMER, K., (2016), CO2 emissions from international shipping. Possible reduction targets and their associated pathways, UMAS.

61. SØRGARD, E., LEHMANN, M., KRISTOFFERSEN, M., DRIVER, W., LYRIDIS, D. and ANAXGOROU, P., (1999), Data on consequences following ship accidents, Safety of shipping in coastal waters (SAFECO II), DNV, WP III.3, D22b.

62. TAN, X., TAOB, J. and KONOVESSISC, D., (2019), Preliminary design of a tanker ship in the context of collision-induced environmental-riskbased ship design, Ocean Engineering, 181, 185197.

63. UNCTAD, 2020, Review of Maritime Transport (2019), Geneva, United Nations.

64. WANG, H., OGUZ, E., JEONG, B. and ZHOU, P., (2018), Life cycle cost and environmental impact analysis of ship hull maintenance strategies for a short route hybrid ferry, Ocean Engineering 161, 20-28. 